\title{
Towards Healthier Life: Changes in growing of health- friendly food crops and products in Lithuania before accession to EU and after
}

\section{Agota Giedrè Raišienè, Mangirdas Morkūnas}

\author{
Lithuanian Institute of Agrarian Economics, Vilnius, Lithuania
}

Keywords:

Diet

Health

EU

Lithuania

Rural area

\section{Article history:}

Received

25.05.2018

Received in revised

form 20.06.2018

Accepted 29.06.2018

\section{Corresponding}

author:

Agota Giedre

Raišienè

E-mail:

agotagiedre@

gmail.com

DOI:

$10.24263 / 2304-$

974X-2018-7-2-16

\section{Abstract}

Introduction. The purpose of the article - based on analysis of statistical data to evaluate how the ratio of health friendly food crop changed before Lithuania entered EU in 2004 and after accession to the EU (2005-2017).

Materials and methods. The statistical data from Lithuanian National Statistical Office and Lithuanian Customs Office has been used. Data lines vary from 1995-2017, to 2004-2017. The content, comparative, statistical analysis, systematization, and scientific interpretation scientific methods have been employed.

Results and discussion. The analysis of statistical data shows the clear drift from traditional and healthier crops and products to ones that are easier to grow and are in demand in the World market. It was caused by the implementation of EU Common Agricultural Policy (CAP) financial mechanisms into Lithuanian agrarian policy. The direct payments for owning land, but not for growing particular crops, create a deficit in various types of food products, considered health inducing. Such a form of financial support of farmers made new EU Member States even more dependable on food import, than before accession into EU.

Because of the current form of agricultural support mechanism, it becomes a hard task to preserve traditional crop varieties in smaller new EU Member States, as it do not have a demand on a World market, so the growing of it seems unprofitable for the farmers at present moment. Unfortunately, if it will change in the future, the farmers will not have the capacity to renew the cultivation of these crops and it will be lost.

The EU CAP also serves as a mechanism for tackling unemployment in rural areas of EU Member States, promoting the agricultural business. Although, the current form of support mechanism, there a financial support is directly linked with the land farmer/ agricultural entity owns, creates a situation, there bigger and stronger farmers get more money, than the ones, that are weaker and own smaller land area. It increases the disparity between rich and poor and can lead to disappearance of smaller farmers.

Conclusions. EU CAP fully achieves it' primary goal - to provide EU Member States citizens with safe and affordable food, but it does not fully fulfill (at least in new Member States) the secondary task - to stimulate the consumption of health inducing diet in EU. 


\section{Introduction}

Thus, the EU food policy takes care of consumer protection and states that it is important not only to seek safe food consumption, but also to promote healthy food consumption. As EU is trying to be self-sufficient in food production, EU food policy (EU, 2007) and EU Common Agricultural Policy (CAP) become interconnected and partly follow the same goals, one of them - enhancing wellness of EU Member States citizens through providing access to cheap, safe and healthy food.

Moreover, in the context of the new EU financial period, it is particularly relevant to review the EU's common policies and to evaluate programs funded from the general EU budget. As for the EU CAP is allocated up to $38 \%$ from the general budget of the EU [1], plus some programs are also partly supported by the Member States themselves, so it is important both on a state and EU level to determine, how effectively the objectives of CAP are being implemented.

Taking into account the above mentioned topicality, the aim of this research paper is formulated as follows: based on analysis of statistical data to evaluate how the ratio of health friendly food crop changed before Lithuania entered EU (till 2004) and after accession to the EU (2005 - 2017). I order to achieve the aim of an article, three healthfriendly crops and food products (fruits and vegetables, beef, fish) have been selected, what are commonly referred in a scientific publication, aimed at revealing food influence and its effects on health. There are also three crop cultures and products identified as unfavorable or less favorable to health, it is - pork, wheat, and sugar.

Article consists of three parts. The first part introduces the essence of the EU Common Agricultural Policy and a mechanism of financial support to EU farmers. Second part presents products, that. According scientific literature and EU Food Policy are considered health inducing and, in contrary, suggested to be avoided in order to keep healthy diet. The main results are presented in the third part of an article, there the analysis of a changing crop cultures and animal food products changes in Lithuania after the accession of EU is presented. All the findings and suggestions of an article are presented in the conclusions.

\section{Materials and methods}

With the regard to implement the aim of a article, we employed the content, comparative, statistical analysis, systematization, and scientific interpretation scientific methods. Systematization method helped us to prepare a theoretical background for our research. The content analysis initially dealt with 'the objective, systematic and quantitative description of the manifest content of communication' (Berelson, 1952) but, nowadays this concept has been expanded and also accommodates interpretations of latent content. We employed it during the official EU documents and scientific papers, aimed at revealing the EU Policy mismatches, analysis. Comparative analysis is a main tool for the researches in social sciences (Mahoney, Rueschmeyer, 2003) and can hardly be avoided in seeking the explanations of complex, dynamic, interconnected processes that not always can be described in simple causal-effect relations. This method was used combined with statistical data analysis in seeking to detect the trends of ongoing processes in Lithuanian agricultural sector and its causes. The logic of selecting products for the research is presented in the previous part of the article. The data lines vary because of availability of reliable data is different in different data bases of Lithuanian National Statistical Office and Lithuanian Customs Office. Scientific interpretation allowed us to look deeper into the causes and preconditions of current developments in Lithuanian agricultural sector, as well as to draw the overall conclusions. 


\section{Results and discussion}

\section{Essence of CAP}

European integration, that started in 1951 by creating European steel and coal community, which was based on supranational authorities on independent states resources laid a foundation not only to peace in Europe (the main goal of European integration, which was obviously achieved, as Europe now faces more than 70 years of continuous peace longest peaceful period in its his history), but also to one of the highest living standards in the world. This was achieved by combining a supranational authority's ability to coordinate and manage the interests of all involved parties on a strategic level with local governments' incentives and knowledge of local traditions, mentality and specifics of challenges faced by each citizen. European Coal and Steel Community evolved into European Economic Community in 1957, which main goal was expanded, compared to ECSC goal and included also the continuing growth of wellness of its respected member states citizens by creating common market, ensuring free flow of goods, services, capital and labor within its borders, fighting social exclusion, ensuring technology and innovations based economy growth and etc. One of a first challenges EEC faced - repeating food shortages in post war Europe [2]. Common challenges created prerequisites for applying a supranational authority's coordination into practice. Such a decision was implemented because of the following reasons: if EEC members would start solving such an important issue independently it would inevitably lead to protectionism, what would contradict not only to free market goal, but also to prerequisite of peace - a free access to all resources in all EU member states. Taking into account those possible negative effects and the importance of challenge - EEC food security, the first truly supranational authority in the World was created and implemented.

The Common Agricultural Policy, introduced in 1962, was aimed at providing Europeans with sufficient amount of food by supporting farm modernization and encouraging rural citizens of European Economic Community to stay in their villages and be engaged in agricultural activities instead of going into overcrowded cities and raise unemployment there. Even though taking into effect in 1966 as a compromise after one of the first major disagreements in EEC history (Empty Chair Crisis) it allocated $78 \%$ of the whole EEC budget [3]. Such a generous financial support mechanism for agricultural products producers (farmers) is based on an assumption, that food is a commodity, which does not fall under the typical economical rules. It is assumed, that lowering prices on food products would only barely increase its consumption, but a food shortage would boom the prices. So, to get bigger profits farmers may not produce so much food and get the same or even bigger amounts of money by creating food shortages and leaving a threat of malnutrition to poorer citizens of EEC, as even the small changes in food supply, could have substantial influence on prices. The solution was to financially support farmers in order to originate EEC with food production capabilities if for some reasons world market would become inaccessible. The chosen mechanism was very simple: the more you produce - more money you get. Such a financial support scheme created a food surplus already in 1970s. After main goal - providing EEC members with cheap and abundant food was accomplished, CAP was modified in order to guarantee employment in rural areas provide and to provide safe and nutritious food. Safe and nutritious food is one of the preconditions to the wellness of EU member states citizens, which is one of the main objectives of the whole EU [4]. It can be noticed, that achieving these two goals simultaneously created new challenges. With the aim to guarantee employment in rural areas, direct payment system to 


\section{Economics and Management -}

farmers (farming entities) was implemented. It focuses not on the production of agricultural products, but on a land owned (or leased) by the farmer and appears as payments per hectares of crop land or numbers of livestock. Direct payment system consists of two parts. One part, of direct payments is being paid regardless crop type and do not vary - a fixed amount of money per hectare. It can be presumed, what his part is being oriented at keeping EU citizens, engaged in agriculture at their farms, paying them and supporting rural employment in such a way. Plus, a constant and guaranteed payment provides farmers with predictable and stable cash flows, as farming is a risky business because of dependency on weather conditions. Second part is being paid according the crop variety, which has been planted. There is a room for maneuver for EU Member States governments to facilitate the cultivation of crops, what it considers to be more valuable to its citizens' health, o should be saved from disappearance [5]. But the tendencies observed show quite a different situation.

The selected type of support mechanism created prerequisites for EU inability to produce enough various food products to its citizens in nearest future. Farmers started to grow not the most beneficial crops to human health or to produce the most nutrient and healthy food products for inner EU market, but started growing crops, that require the least efforts to produce and can be easily sold in worldwide markets. The growing demand for biofuels encouraged some Lithuanian farmers to switch to rape growing thus reducing food crop area. CAP not only changed the traditional agricultural product portfolio of some EU member states, but even created a risk of disappearance of some traditional crops from the map.

It can't be said, what the governments of an EU Member States (especially newly accepted members) do not notice such a shift from more healthy crops to more desirable in international markets. It may seem, what biggest farmers or agricultural entities are solving one of the biggest problems of Central and Eastern Europe's countries - chronical budget deficit (in past 10 years Latvia, Poland, Hungary, Romania had budget deficit all 10 consequently years, Lithuania -8 and etc. [6]. Growing crops, that are marketable worldwide creates foreign currency and cash flow incomes to the country, helps to fill in the budget. But it comes at the expense of changing portfolio structure of crops cultivated, what, indirectly influences the eating habits of EU member states citizens. Here we observe the dichotomy in objectives raised by CAP, and objectives achieved under its support mechanisms. In order to analyze, how CAP financial support mechanisms helped to achieve one of the main CAP and health promotion [7] objectives - to increase production and consumption of more healthy food - we made an analysis of statistical data in one of EU new comer Lithuania.

\section{European health inducing policy}

One of the main aims of EU is the wellness of citizens of all Member States. It consists not only of economic prosperity, which is unimaginable without healthy population, able of working creating and collaborating, but also of healthy aging and enjoying the life at any age. A lot of diseases and factors, causing disability, partial disability or constraints, interfering the satisfaction with the life lived relate to diet. It is the reasons, thy European Commission driven by the goal of enhancing the wellness of citizens of its Member States allocated 80 billion EUR of its budget to Horizon 2020 programs, one of them is promoting the "research on healthy foods and diets focuses on the nutritional needs and the impact of food on physiological functions and physical and mental performance. The activities aim at studying the links between diet, ageing, chronic disease and disorders and dietary patterns 


\section{- Economics and Management -}

and aim to identify dietary solutions and innovations leading to improvements in health and well-being" [8]. Such a focus on healthy food in EU clearly shows the actuality of the researches, aimed on revealing, how the EU promotes the healthy diet of its citizens. To contribute to this aim, we selected the following products presented in the article below and observed, how the EU CAP as one of the instruments to achieve main EU goals contributes to inducing healthy diet.

\section{Products considered as having potential negative health effect}

Malik et al. [9] research shows correlation between consuming animal fat (especially pork), added sugars and refined grains with increased endocrinal illnesses and obesity. Obesity leads to cardiovascular diseases, diabetes [10], more complicated pregnancy [11], lowers functional capacity of persons [12]. Wheat is considered less health-friendly, because it is usually consumed highly processed in final food products, what leads to high levels of gluten in it. Koning [13] emphasizes the toxicity of wheat gluten. Aronsson et al. [14] states, that gluten rich products, especially manufactured from highly processed wheat has long lasting negative effects on humans' health and twice fold increase the chances of celiac disease to children. Consuming gluten rich products lead to increased risk of allergic diseases [15]. It is advisable to substitute processed wheat products in order to lower the allergy [16], intestinal cancer [17], autism [18] [19] prevalence in society.

Pork fat is considered unhealthy and consumption of products, containing pork fat is not recommended both by European Food Safety Authority and World Health Organization [20]. Consumption of pork creates negative cardiovascular effects: coronary heart disease, stroke and hypertension. Also processed pork has adversely effect on oncological diseases consumption of it can lead to colorectal cancer [21], although it is worth mentioning, what the clear mechanism how processed pork meat induces colorectal cancer is still unknown [22]. Higher levels of cholesterol in blood, which is closely linked with the consumption on triglycerides and fatty acids found in pork meat may lower the quality of life even for persons, who still did not develop such an adverse effect like cancer or coronary disease [23]. Such people show signs of earlier fatigue, are less productive.

Malik and $\mathrm{Hu}$ [24] showed clear dependency between sugar consumption and increased risk of obesity, type 2 diabetes and cardiovascular diseases. Kearns et al. [25] also focus their research to coronary diseases and sugar intake, showing, that such a dependency has been observed for almost 50 years. American Heart Association [26] stresses sugar containing diet influence on children cardiovascular disease risk. Lowette et al. [27] showed, that a diet with high content of sugar may lead to adverse effects in human's cognitive function, impaired learning and memory. Similar results have been published by Hsu et al. [28].

\section{Products recommended for a health inducing diet}

The consumption of beef is preferential compared to pork and recommended in order to maintain healthy diet [29] [30]. The main focus on promoting beef meat lies not in its containment of high quality protein, iron, zinc, vitamin D, B3, B12, selenium and longchain omega-3 fatty acids what have positive potential impact on human health, but also in its capability to substitute pork, considered not favorable in terms of healthy diet, in almost all traditional European dishes containing red meat. Also beef meat is considered much healthier than pork [31] as it is important dietary source of CLA, especially cis-9, trans-11 isomer, identified as an important health promoter factor including antitumor and ant 
carcinogenic activities [32], beef also contains specific trans-fatty acids, that have potential protective properties against the development of coronary heart diseases [33].

Lampe [34] argues, that fruits and vegetables are the consistent parts of diet, which should be consumed most. The phenolics, found in fruits and berries show a wide range of antioxidant activities [35] and are thought to exert protective effects against major diseases such as cancer and cardiovascular diseases. Other researches [36] praise anthocyanins, found in berries and fruits, and its positive health effects. There are abundant of scientific literature [37], [38], [39] on positive effects of vitamins and minerals found in fruits and berries. Rodriguez-Casado [40] show fruits antimicrobial features.

Lithuanian Ministry of Health [41] strongly recommends increasing fish and fish products proportion in Lithuanians diet. Krumhout \& de Goede [42] researching $\omega-3$ fatty acids, found in fish concluded that there is strong evidence for a protective effect of $\omega-3 \mathrm{FA}$ on fatal CHD and for some markers of atherosclerosis and thrombosis. $\Omega-3$ fatty acids also reduced markers of ventricular fibrillation. Mozaffarian \& Wu [43] research also confirms positive cardiovascular effects of diary consumption of fish fatty acids. Imhoff-Kunsch et al. [44] research showed what consumption of n-3 Long-chain Polyunsaturated Fatty Acid reduced risk of preterm delivery by $26 \%$. Raji et al. [45] study showed positive effect of fish consumption to age-related brain gray matter loss. Butler et al. [46] research shows a positive link between fish consumption and neuropsychological performance. Gil \& Gil [47] found, that fish consumption is associated with lower markers of inflammatory processes.

\section{Changes in growing of health-friendly food crops and products in Lithuania between 1995 and 2017}

Pork. Production of pork meat, that traditionally was on an equal terms (or was produced a bit less compared to beef in Lithuania) in production in Lithuania has increased significantly in the first years after Lithuanian entrance to EU. The increase is about 20 percent. The following growth was limited be swine fever, that occurred in 2009 and once again in 2016. After this event, following EU regulation, as a preventive countermeasure to avoid future outbreaks of this disease the liquidation of all pigs grown in small and medium farms was implemented. These actions eliminated a competition that was starting to occur in Lithuanian pork production sector, reserving this market only to bigger producers and other EU member states farmers. The growth in pork meat production correlates with the decrease in beef production, which was traditional in Lithuanian cuisine, has long-lasting traditions and is not, only a good substitution to pork in almost all meals, but is also considered much healthy than pork.

Beef. The production of beef meat has dropped by 22 percent on average if comparing periods from 1995 to 2004 and from 2005 and 2017. The biggest drop in agricultural production of beef was in the first years Lithuania entered EU, from 2005 to 2013. In this financial perspective the production of beef in Lithuania decreased by 30 percent. During the financial perspective, which begun in 2014 (should last until 2020) the production of beef stabilized at around 73 percent of pre entrance to EU level. 
Production of fresh pork meat in Lithuania

\begin{tabular}{|c|c|c|c|}
\hline Year & $\begin{array}{c}\text { Quantity, } \\
\text { thousands of tons }\end{array}$ & Year & $\begin{array}{c}\text { Quantity, } \\
\text { thousands of tons }\end{array}$ \\
\hline 1995 & 115,5 & 2004 & 136,3 \\
\hline 1996 & 109,9 & 2005 & 148,4 \\
\hline 1997 & 107,7 & 2006 & 151,3 \\
\hline 1998 & 116,6 & 2007 & 141,2 \\
\hline 1999 & 112,7 & 2008 & 104,8 \\
\hline 2000 & 102,8 & 2009 & 84,4 \\
\hline 2001 & 88 & 2010 & 103,9 \\
\hline 2002 & 116,3 & 2011 & 108,9 \\
\hline 2003 & 125,5 & 2012 & 111,8 \\
\hline & & 2013 & 122,9 \\
\hline & & 2014 & 118,9 \\
\hline & & 2015 & 121 \\
\hline & & 2016 & 105,8 \\
\hline & & 2017 & 100,3 \\
\hline
\end{tabular}

Production of fresh beef meat in Lithuania

Table 2

\begin{tabular}{|l|r|l|r|}
\hline Year & $\begin{array}{l}\text { Quantity, } \\
\text { thousands of tons }\end{array}$ & Year & $\begin{array}{l}\text { Quantity, } \\
\text { thousands of tons }\end{array}$ \\
\hline 1995 & 146,2 & 2004 & 97,6 \\
\hline 1996 & 139,1 & 2005 & 110,1 \\
\hline 1997 & 150 & 2006 & 93,4 \\
\hline 1998 & 141,1 & 2007 & 112,4 \\
\hline 1999 & 127,5 & 2008 & 90,6 \\
\hline 2000 & 125,9 & 2009 & 88 \\
\hline 2001 & 79,9 & 2010 & 89,6 \\
\hline 2002 & 74,8 & 2011 & 86,4 \\
\hline 2003 & 86,3 & 2012 & 84,8 \\
\hline & & 2013 & 77,1 \\
\hline & & 2014 & 82,8 \\
\hline & & 2015 & 93,1 \\
\hline & & 2016 & 88,9 \\
\hline & & 2017 & 85,3 \\
\hline & & &
\end{tabular}


Grain: Wheat and rye. The most drastic changes are being observed in grain growing in Lithuania. Historically rye was more prevalent in Lithuania, than wheat [48]. It has become a part of Lithuanian traditions, as traditional rye bread or rye vodka, as well, as other dishes ("kleckai" ( kind of rye dough dumplings) and etc.) are included into the list of Lithuanian national heritage. Unfortunately, the trends in agricultural production in Lithuania put these products under risk of disappearance, as the growing of rye has decreased dramatically. The trend, of shifting from rye to wheat in Lithuania was observed even before entrance into EU (Table no. 3), but after accession then CAP came into effect, the substitution of rye with wheat in the portfolio of Lithuanian farmers became dangerous from the traditions saving side. Lithuania has already lost one of very important traditional crops - flax has disappeared from list of crops grown by Lithuanian farmers, although flax has been an important crop in Lithuania [49] for centuries.

Harvest of wheat and rye in Lithuania in thousands of tons

Table 3

\begin{tabular}{|c|c|c|c|c|c|c|c|}
\hline Year & Wheat & Rye & $\begin{array}{c}\text { Rye/wheat } \\
\text { ratio }\end{array}$ & Year & Wheat & Rye & $\begin{array}{c}\text { Rye/wheat } \\
\text { ratio }\end{array}$ \\
\hline 1995 & 637,3 & 239,3 & $266,3 \%$ & 2004 & 1430,2 & 140,6 & $1017,2 \%$ \\
\hline 1996 & 936,2 & 286,8 & $326,4 \%$ & 2005 & 1379,4 & 108,3 & $1273,7 \%$ \\
\hline 1997 & 1127,4 & 348,2 & $323,8 \%$ & 2006 & 809,8 & 90 & $899,8 \%$ \\
\hline 1998 & 1031 & 348,7 & $295,7 \%$ & 2007 & 1390,7 & 165,2 & $841,8 \%$ \\
\hline 1999 & 870,9 & 260,9 & $333,8 \%$ & 2008 & 1722,5 & 204,9 & $840,7 \%$ \\
\hline 2000 & 1237,6 & 311,4 & $397,4 \%$ & 2009 & 2100,2 & 207,9 & $1010,2 \%$ \\
\hline 2001 & 1076,3 & 231,1 & $465,7 \%$ & 2010 & 1710,4 & 87 & $1966,0 \%$ \\
\hline 2002 & 1217,6 & 170,2 & $715,4 \%$ & 2011 & 1869,3 & 85 & $2199,2 \%$ \\
\hline 2003 & 1204,1 & 147,1 & $818,6 \%$ & 2012 & 2998,9 & 156,6 & $1915,0 \%$ \\
\hline & & & & 2013 & 2871,3 & 96,5 & $2975,4 \%$ \\
\hline & & & & 2014 & 3230,6 & 85,3 & $3787,3 \%$ \\
\hline & & & & 2015 & 4380,3 & 107,8 & $4063,4 \%$ \\
\hline & & & & 2016 & 3844,5 & 77,5 & $4960,6 \%$ \\
\hline & & & & 2017 & 3917,4 & 63,1 & $6208,2 \%$ \\
\hline
\end{tabular}

The shrinking part of rye in crop structure in Lithuania also has a negative health effect. Rye bread, compared to wheat bread, has some positive effects. One of them lowers the level of cholesterol in blood [50]. The cholesterol is seen as one of the prerequisites for cardiovascular diseases, that are responsible for more than a half of deaths in Lithuania [51]. It is important to mention, that both rye and wheat contain gluten, but traditionally rye was used in Lithuania in a much less refined form and all the traditional Lithuanian dishes are being prepared from much less refined rye than nowadays consumed wheat.

Such a huge growth in wheat production, what has overcome the needs of Lithuania by $2,5 \mathrm{mln}$. tons has a quite simple explanation. Wheat is a commodity, traded in a world market, has a demand Worldwide as owing to globalization processes Western - style food is getting popular even in regions, previously dominated by Asian or African cuisine [52] [53]. Such a situation is quite comfortable for EU decision makers, as helps to maintain positive trade balance of EU (wheat is much easily traded abroad than rye), helps to keep 
low levels of unemployment in rural areas of EU members (especially new ones) at low costs, do not require to relocate big manufacturing facilities from older EU members to new ones in order to tackle unemployment. The promotion of production of low value-added products (agricultural production) in new EU member states do not create a competition to older EU members in terms of economic competitiveness, makes them dependent on older EU members, somehow diminishing the influence of new EU members on decision making process in Brussels.

Fruits and berries. Trends in fruits and berries (because Lithuanian National Statistical Office provides data only on apple, pear, black, red, white currant, cherry, plum, strawberry and raspberry production in Lithuania, only data of these fruits and berries is taken into consideration. It should be mentioned, that reliable and accurate statistical data on fruits and berries production in Lithuania appeared only after accession to EU. Because of that reason, data from 2005 has been analyzed. As 2005 and 2006 show similar results, it can be presumed, that in previous years harvests appeared to be on a comparable levels) show the same negative trend. According Lithuanian National Center for Health Encouraging and Disease Prevention [54] fruits and berries are among products, whose consumption should be promoted on a country scale, as it has positive health benefits.

\section{Harvest of fruits and berries in Lithuania in thousands of tons}

Table 4

\begin{tabular}{|c|c|}
\hline Year & $\begin{array}{c}\text { Fruits and berries, } \\
\text { thousands of tons }\end{array}$ \\
\hline 2005 & 224,4 \\
\hline 2006 & 231,5 \\
\hline 2007 & 100,7 \\
\hline 2008 & 171,6 \\
\hline 2009 & 133,5 \\
\hline 2010 & 84,4 \\
\hline 2011 & 116 \\
\hline 2012 & 164,2 \\
\hline 2013 & 143,7 \\
\hline 2014 & 137,4 \\
\hline 2015 & 168,3 \\
\hline 2016 & 151,6 \\
\hline 2017 & 162,9 \\
\hline
\end{tabular}

Although statistical data shows a high decrease in Lithuanian production of traditional local fruits and berries (see Table No. 4). The production levels of these agricultural products after entrance to EU is only at the level of $2 / 3$ of previous production and do not show the signs of recovery as a big part of apple orchard has been abandoned or destroyed in order to use the land for wheat and rape growing and it takes form 5 to 7 years, till newly planted orchards become productive, even if the initiatives in promoting local fruit production would occur. The results shown in a table are not so disappointing because of growing harvests of black currant, whose export is booming [55]. Such an artificially created deficit in fruit and berries production was covered by fruit import. Main Lithuanian fruits and berries import partners after accessing EU became Spain and Italy. 
Import of fruits and berries to Lithuania in millions of Euro

\begin{tabular}{|c|c|c|c|}
\hline Year & $\begin{array}{c}\text { Import of } \\
\text { fruits and berries, } \\
\text { mln. EUR }\end{array}$ & Year & $\begin{array}{c}\text { Import of } \\
\text { fruits and berries, } \\
\text { mln. EUR }\end{array}$ \\
\hline 1999 & 61,6 & 2004 & 89,8 \\
\hline 2000 & 63,4 & 2005 & 109,2 \\
\hline 2001 & 63,2 & 2006 & 191,2 \\
\hline 2002 & 65,4 & 2007 & 244,6 \\
\hline 2003 & 75,2 & 2008 & 352,1 \\
\hline & & 2009 & 256,8 \\
\hline & & 2010 & 350,2 \\
\hline & & 2011 & 415,5 \\
\hline & & 2012 & 505,3 \\
\hline & & 2013 & 542,2 \\
\hline & & 2014 & 508,8 \\
\hline & & 2015 & 564,7 \\
\hline & & 2016 & 365,4 \\
\hline & & 2017 & 422,1 \\
\hline
\end{tabular}

It corresponds to some alternative economic ideas [56] that newly accepted EU members become an open market for products from older member states.

Sugar beets. Even though sugar has been considered very harmful to humans health, and products, containing high to moderate amounts of sugar (sweets, chocolates, cakes, pies and etc.) are banned in Lithuanian schools and kindergarten, its production do not decrease after Lithuanian access to EU. Sugar beets production drop in 2008 was influenced by bankruptcy of one of the biggest Lithuanian sugar producers, which could not to withstand competition from other EU sugar producers, but not by common EU policy. Stable sugar beets production is maintained through quota system.

Fish. The results of fish catches are affected by quota system implemented in a whole EU and based on pre-Entrance levels of catches of each member state. It is not very thorough, as before entering the EU, some of newly accepted member states had an outdated fishing fleet, some disorder in an organization of fishing activities. Such a situation resulted in lower catches of fish in open seas for particular period. It was reflected in quotas that are lower than a potential of some new member states to enhance their fishing capabilities. Because of that, new member states are locked in lower fish catches having no legal rights to catch more fish and to deliver it to states consumers.

It is worth mentioning, what data on fish catches was provided by Eurostat and for the moment of preparation of an article an official data on Year 2017 was not available.

Summarizing the above mentioned, we can state, that the aim of supporting the healthier diet of an EU citizens is not fully achieved by current form of CAP, as it do not guarantee the basis for healthy diet - the production of health inducing agricultural products at least in new EU Member States. It shaped the portfolio of grown agricultural crops and in that way, what it even can raise an assumption, that Common EU agricultural policy serves 
not as a trigger for more healthy, nutritious food production, which should contribute to a higher levels of EU member states citizens living quality, but as a tool to help to improve a EU foreign trade balance by growing easily sold in Worldwide markets low value added products in new EU Member States.

Sugar beets production in Lithuania in thousands of tons

Table 6

\begin{tabular}{|c|c|c|c|}
\hline Year & $\begin{array}{c}\text { Sugar beets production, } \\
\text { thousands of tons }\end{array}$ & Year & $\begin{array}{c}\text { Sugar beets production, } \\
\text { thousands of tons }\end{array}$ \\
\hline 1995 & 692,4 & 2004 & 904,9 \\
\hline 1996 & 795,5 & 2005 & 798,5 \\
\hline 1997 & 1001,9 & 2006 & 717,1 \\
\hline 1998 & 949,2 & 2007 & 799,9 \\
\hline 1999 & 869,9 & 2008 & 339,1 \\
\hline 2000 & 881,6 & 2009 & 682 \\
\hline 2001 & 880,4 & 2010 & 706,7 \\
\hline 2002 & 1052,4 & 2011 & 877,8 \\
\hline 2003 & 977,4 & 2012 & 1003 \\
\hline & & 2013 & 967,1 \\
\hline & & 2014 & 1014,4 \\
\hline & & 2015 & 619,5 \\
\hline & & 2016 & 933,5 \\
\hline & & 2017 & 956,9 \\
\hline
\end{tabular}

Table 7

Catches of fish in Lithuanian territory or by ships with Lithuanian flag in thousands of tons

\begin{tabular}{|c|c|c|c|}
\hline Year & $\begin{array}{c}\text { Catches, } \\
\text { thousands of tons }\end{array}$ & Year & $\begin{array}{c}\text { Catches, } \\
\text { thousands of tons }\end{array}$ \\
\hline 2000 & 77.077 & 2004 & 160.222 \\
2001 & 148.977 & 2005 & 138.166 \\
2002 & 149.388 & 2006 & 153.113 \\
2003 & 155.246 & 2007 & 149.733 \\
& & 2008 & $157.104,9$ \\
& & 2009 & $150.094,6$ \\
& & 2010 & $138.244,7$ \\
& & 2011 & 137.085 \\
& & 2012 & $70.195,04$ \\
& & 2013 & $74.802,81$ \\
& & 2014 & $148.842,76$ \\
& & 2015 & $72.432,13$ \\
& & 2016 & $105.738,74$ \\
\hline
\end{tabular}




\section{Economics and Management -}

\section{Conclusions}

CAP is an effective tool in providing citizens of EU Member States with safe and affordable food. It also acts as a social support mechanism, ensuring livability of rural areas by enhancing employment in farming industry through the financial support system. Although, it can be noticed, that CAP implementation mechanism does not pay too much attention to the crops and products grown by farmers' portfolio structure, and only focuses on effective use of land. Such an attitude leads to a situation, that farmers start to grow crops, not the most favorable for Member States citizens' health, but the most appreciated in the World market. This creates a big surplus of agricultural products of one or other variety (typically not the most health inducing) and creates a big deficit, or even threatens of disappearance of other varieties.

The big focus on agricultural sector, caused by the CAP financial mechanisms is also twofold. On the one hand, it helps to tackle unemployment in rural areas and to keep the living standards in rural areas comparable to at least the living standards of a middle class in urban areas, on the other hand, it locks the citizens of rural areas into low value-added industry, which is primarily dependent on EU financial mechanisms for survivability, so very sensitive to any changes in Brussels policy. Such a big and obvious risk may slow the investments into rural areas, as no one can guarantee, that EU attitude towards CAP and its financial mechanisms will not change and affect the return on investment.

It can be presumed, although it requires deeper researches to fully substantiate, that $\mathrm{CAP}$ acts as a tool to make newcomers of EU more compliant. It is hard to stand firm on contradictory position in EU negotiations, because employment, living standards and quality of life in rural areas in home countries of EU newcomers is dependent on current CAP financial mechanisms and even the small adjustment in policy may have significant consequences which countries cannot afford.

\section{References}

1. Bruegel (2018), EU budget, Common Agricultural Policy and Regional Policy - en route to reform?, Available at: http://bruegel.org/2018/02/eu-budget-common-agricultural-policyand-regional-policy-en-route-to-reform/.

2. European Union official gazette. The history of the European Union, Available at: https://europa.eu/european-union/about-eu/history_en .

3. European Union official gazette. The common agricultural policy at a glance, Available at: https://ec.europa.eu/info/food-farming-fisheries/key-policies/common-agriculturalpolicy/cap-glance_en\#why.

4. EU Treaty, Available at: https://europa.eu/europeanunion/sites/europaeu/files/docs/body/treaty_on_european_union_en.pdf.

5. European Union official gazette. Agriculture and rural development, Available at: https://ec.europa.eu/agriculture/direct-support/direct-payments_lt

6. Eurostat (2018), General government deficit (-) and surplus ( $\left.+{ }^{-}\right)$- annual data, Available at: $\mathrm{http}: / /$ ec.europa.eu/eurostat/tgm/table.do?tab=table\&plugin=1 \&language=en\&pcode=teina2 00 .

7. European Commission (2007), Strategy on nutrition, overweight and obesity-related health issues, Available at:

https://ec.europa.eu/health/nutrition_physical_activity/policy/strategy_en 


\section{- Economics and Management -}

8. European Commission (2014), Framework Programmes for Research and Technological Development. Horizon 2020. Food \& Healthy Diet, Available at: https://ec.europa.eu/programmes/horizon2020/en/area/food-healthy-diet.

9. Malik V.S., Pan A., Willett W.C., Hu F.B. (2013), Sugar-sweetened beverages and weight gain in children and adults: a systematic review and meta-analysis, The American Journal of Clinical Nutrition, 98(4), pp. 1084-1102, DOI: 10.3945/ajcn.113.058362.

10. The GBD Obesity Collaborators (2017), Health Effects of Overweight and Obesity in 195 Countries over 25 Years. New England Journal of Medicine, 377, pp.13-27, DOI: 10.1056/NEJMoa1614362.

11. Linne Y. (2004), Effects of obesity on women's reproduction and complications during pregnancy. Obesity reviews, (5), (3), pp. 137-143.

12. Pataky Z., Armand S., Muller-Pinget S., Golay A., Allet L. (2014), Effects of Obesity on Functional Capacity. Obesity, (22), pp. 56-62. doi:10.1002/oby.20514

13. Koning F. (2015), Adverse Effects of Wheat Gluten. Annals of Nutrition and Metabolism, (67), (2), pp. 8-14

14. Arronson C.A., Lee H.S., Koletzko S., Uusitalo U., Yang J., Virtanen S.M., Liu E., Lernmark A., Noris J.M., Agardh D. (2016), Effects of Gluten Intake on Risk of Celiac Disease: A Case-Control Study on a Swedish Birth Cohort, Clinical Gastroenterology and Hepatology, (14), (3), pp. 403-409.

15. Scharf A., Kasel U., Wichmann G., Besler M. (2013), Performance of ELISA and PCR Methods for the Determination of Allergens in Food: An Evaluation of Six Years of Proficiency Testing for Soy (Glycine max L.), and Wheat Gluten (Triticum aestivum L.), Journal of Agricultural Food Chemistry., 61(43), pp. 10261-10272, DOI: $10.1021 / \mathrm{jf} 402619 \mathrm{~d}$

16. Bessler (ed.), (2014), Allergens III: $\beta$-Lactoglobulin and Gluten in Infant Food. Evaluation Report, Available at:

https://www.researchgate.net/profile/Matthias_Besler/publication/274370609_Proficiency_ Test_Report_DLA_032014_Allergens_III_beta-

Lactoglobulin_and_Gluten_in_Infant_Food/links/551bf2f70cf2909047b98186.pdf

17. Sur D.G., Mihaela B., Floca E., Sur G. (2017), Intestinal Cancer in Celiac Disease, International Journal of Celiac Disease, 5(1), pp. 28-29, DOI:10.12691/ijcd-5-1-9.

18. Ghalichi F., Ghaemmaghami J., Malek A., Ostadrahimi A. (2016), Effect of gluten free diet on gastrointestinal and behavioral indices for children with autism spectrum disorders: a randomized clinical trial, World Journal of Pediatrics, 12(4), pp. 436-442

19. Elder J.H., Shankar M., Shuster J., Theriaque D., Burns S., Sherrill L. (2006), The GlutenFree, Casein-Free Diet In Autism: Results of A Preliminary Double Blind Clinical Trial, Journal of Autism and Developmental Disorders, 36(3), pp. 413-420.

20. Mora-Galego H., Serra X., Guardia M.D., Arnau J. (2014), Effect of reducing and replacing pork fat on the physicochemical, instrumental and sensory characteristics throughout storage time of small caliber non-acid fermented sausages with reduced sodium content, Meat Science, 97(1), pp. 62-68, DOI: 10.1016/j.meatsci.2014.01.003

21. Demeyer D., Honikel K., De Smet S. (2008), The World Cancer Research Fund report 2007: A challenge for the meat processing industry, Meat Science, 80, pp. 953-959

22. Grasso S., Brunton N.P., Lyng J.G., Lalor F., Monahan F.J. (2014), Healthy processed meat products - Regulatory, reformulation and consumer challenges, Trends in Food Science \& Technology, 39(1), pp. 4-17.

23. Vannice G., Rasmussen H. (2014), Position of the Academy of Nutrition and Dietetics: Dietary Fatty Acids for Healthy Adults, Journal of the Academy of Nutrition and Dietetics, 114(4), pp. 136-153. 


\section{- Economics and Management -}

24. Malik V.S., Hu F.B. (2015), Fructose and Cardiometabolic Health What the Evidence From Sugar-Sweetened Beverages Tells Us, Journal of the American College of Cardiology, 66(14), pp. 1615-1624, DOI: 10.1016/j.jacc.2015.08.025.

25. Kearns C.E., Schmidt L.A., Glantz S.A. (2016), Sugar Industry and Coronary Heart Disease Research. A Historical Analysis of Internal Industry Documents, Jama Internal Medicine, 176(11), pp. 1680-1685, DOI:10.1001/jamainternmed.2016.5394.

26. Vos M.B., Kaar J.L., Welsh J.A., Van Horn L.V., Feig D.I., Anderson Ch., A.M., Patel M.J., Cruz Munos J., Krebs N. F., Xanthakos S.A., Johnson R.K. (2017), Added Sugars and Cardiovascular Disease Risk in Children: A Scientific Statement From the American Heart Association, DOI: 10.1161/CIR.0000000000000439.

27. Lowette K., Roosen L., Tack J., Vanden Berghe P. (2015), Effects of high-fructose diets on central appetite signaling and cognitive function, Frontiers in Nutrition, 2, DOI: $10.3389 /$ fnut.2015.00005.

28. Hsu T.M., Konanur V.R., Taing L., Usui R., Kayser B.D., Goran M.I., Kanoski S.E. (2015), Effects of sucrose and high fructose corn syrup consumption on spatial memory function and hippocampal neuroinflammation in adolescent rats. Hippocampus, 25(2), pp. 227-239, DOI: $10.1002 /$ hipo.22368.

29. McAfee A.J., McSorley E.M., Cuskelly G.J., Moss B.W., Wallace J.M.W., Bonham M.P., Fearon A.M., (2010),. Red meat consumption: an overview of the risks and benefits, Meat Science, 84(1), pp. 1-13.

30. Wezemael L.V., Caputo V., Nayga Jr.R.M., Chryssochoidis G., Verbeke W., (2014), European consumer preferences for beef with nutrition and health claims: A multi-country investigation using discrete choice experiments, Food Policy, 44, pp. 167-176.

31. Troy D.J., Tiwari B.K., Joo S. (2016), Health Implications of Beef Intramuscular Fat Consumption, Korean Journal for Food Science of Animal Resources, 36(5), pp. 577-582, DOI: 10.5851/kosfa.2016.36.5.577.

32. Salter A.M. (2013), Dietary fatty acids and cardiovascular disease, Animal, 7(1), pp. 163171.

33. Pighin D., Pazos A., Chamorro V., Paschetta F., Cunzolo S., Godoy F. Messina V. Pordomingo A., Grigioni G. (2016), A Contribution of Beef to Human Health: A Review of the Role of the Animal Production Systems, The Scientific World Journal, DOI: $10.1155 / 2016 / 8681491$.

34. Lampe J. W. (1999), Health effects of vegetables and fruit: assessing mechanisms of action in human experimental studies, The American Journal of Clinical Nutrition, 70(3), pp. 475490, DOI: $10.1093 / \mathrm{ajcn} / 70.3 .475$ s.

35. Shahidi F., Ambigaipalan P. (2015), Phenolics and polyphenolics in foods, beverages and spices: Antioxidant activity and health effects - A review, Journal of functional foods, (18), pp. 820-897.

36. Fang F. (2015), Classification of fruits based on anthocyanin types and relevance to their health effects, Nutrition, 31(11-12), pp. 1301-1306.

37. Mozafar A. (2017), Plant Vitamins. Agronomic, Physiological, and Nutritional Aspects. 1st ed., CRC Press, ISBN: 978-1315896700.

38. Yahia, E. (ed.), (2017), Fruit and Vegetable Phytochemicals: Chemistry and Human Health, 2nd ed., Wiley-Blackwell, ISBN: 978-1-119-15794-6

39. Park S., Ham J.-O., Ham M.D., Lee B.-K. (2015), Effects of total vitamin A, vitamin C, and fruit intake on risk for metabolic syndrome in Korean women and men, Nutrition, 31(1), pp. 111-118.

40. Rodriguez-Casado A. (2016), The Health Potential of Fruits and Vegetables Phytochemicals: Notable Examples, Critical Reviews in Food Science and Nutrition, 56(7), pp. 1097-1107. 


\section{Economics and Management -}

41. Lithuanian Ministry of Health (2018), Recommendations for healthy diet, Available at: https://sam.lrv.lt/lt/veiklos-sritys/visuomenes-sveikatos-prieziura/mityba-ir-fizinisaktyvumas-2/sveikos-mitybos-rekomendacijos.

42. Krumhout, D., de Goede, J. (2014), Update on cardiometabolic health effects of $\omega$-3 fatty acids, Current Opinion in Lipidology, 25(1), pp. 85-90.

43. Mozaffarian D., Wu J., H.,Y. (2012), n-3 Fatty Acids and Cardiovascular Health: Are Effects of EPA and DHA Shared or Complementary?, The Journal of Nutrition, 142(3), pp. 614-625.

44. Imhoff-Kunsch, B., Briggs, V., Goldenberg, T., Ramakrishnan, U. (2012), Effect of n-3 Long-chain Polyunsaturated Fatty Acid Intake during Pregnancy on Maternal, Infant, and Child Health Outcomes: A Systematic Review, Pediatric and Perinatal Epidemiology, 26(s1), pp. 91-107.

45. Raji C. A., Erickson K.I., Lopez O.L., Kuller L.H., Gach H.M., Thompson P.M., Riverol M., Becker J.T. (2014), Regular Fish Consumption and Age-Related Brain Gray Matter Loss, American Journal of Preventive Medicine, 47(4), pp. 444-451

46. Butler L.J., Janulewicz P.A., Carwile J.L., White R. F., Winter M.R., Aschengrau A. (2017), Childhood and adolescent fish consumption and adult neuropsychological performance: An analysis from the Cape Cod Health Study, Neurotoxicology and Teratology, 61, pp. 47-57, DOI: 10.1016/j.ntt.2017.03.001.

47. Gil A., Gil F. (2015), Fish, a Mediterranean source of n-3 PUFA: benefits do not justify limiting consumption, British Journal of Nutrition, 113(s2), , pp. 558-567.

48. Plyčevaitienè V., Ruzgas V. (2007), Naujų žieminių rugių linijų agronominiai tyrimai, Žemdirbyste். Mokslo darbai, 94(1), pp. 160-170.

49. Jankauskienè Z. (2014), Results of 90 Years of Flax Breeding in Lithuania, Proceedings of the Latvian Academy of Sciences. Section B. Natural, Exact, and Applied Sciences, 68(34),. DOI: 10.2478/prolas-2014-0022.

50. Leinonen K.S., Poutanen, K., S., Mykkanen, H., M. (2000), Rye bread decreases serum total and LDL cholesterol in men with moderately elevated serum cholesterol, The Journal of Nutrition, 130(2), pp. 164-170.

51. Lithuanian National Institute of Hygiene (2017), Paskelbti 2016 m. duomenys apie mirties priežastis Lietuvoje. Official report, Available at: http://www.hi.lt/news/1222/1101/Paskelbti-2016-m-duomenys-apie-mirties-priezastisLietuvoje.html

52. Chiang P-H., Wahlqvist M.L., Lee S-M., Huang L-Y, Chen H-H., Huang S.T-Y. (2011), Fast-food outlets and walkability in school neighbourhoods predict fatness in boys and height in girls: a Taiwanese population study, Public Health Nutrition, 14(9), pp. 16011609.

53. Noubiap J.J.H., Bigna J.J.R., Nansseu J.J.R. (2015), Low Sodium and High Potassium Intake for Cardiovascular Prevention: Evidence Revisited With Emphasis on Challenges in Sub-Saharan Africa, The Journal of Clinical Hypertension, 17(1), pp. 81-83.

54. Lithuanian National Center for Health Encouraging and Disease Prevention (2017), Methodical recommendations for health inducing diet, Available at: http://www.smlpc.lt/media/image/Naujienoms/2017\%20metai/Mityba\%20ir\%20fizinis\%20 aktyvumas/_INFORM_vartotojams_medz_kaip_.pdf .

55. Melnikiene R. (ed.), (2018), Lietuvos žemés ir maisto ükis $2017=$ Agriculture and food sector in Lithuania 2017, Lithuanian Institute of Agrarian Economics. Vilnius, Available at: https://www.laei.lt/x_file_download.php?pid=3151 .

56. Borsi M.T., Metiu $\overline{\mathrm{N}}$. (2015), The evolution of economic convergence in the European Union, Empirical Economics, 48(2), pp. 657-681. 